\title{
Optimization of Nitrogen Fertilization Timing and Rate in Machine Transplanted Rice
}

\author{
P. Raghu Rami Reddy*
}

Agricultural College, Palem, PJTSAU, Hyderabad, India

*Corresponding author

\begin{tabular}{l} 
Key w or d s \\
Machine \\
transplanted rice, \\
$\begin{array}{l}\text { Nitrogen rate and } \\
\text { timing, Grain yield, } \\
\text { Cost economics }\end{array}$ \\
\hline Article Info \\
$\begin{array}{l}\text { Accepted: } \\
\text { 10 October } 2019 \\
\text { Available Online: } \\
\text { 10 November } 2019\end{array}$ \\
\hline
\end{tabular}

A B S T R A C T
Machine transplanted rice (MTR) is an emerging production system in South India to address the labour shortage. No research has been done in this aspect on optimizing nitrogen management to produce high yield. In this study, influence of varying nitrogen rates and time of application were studied with respect to grain yield, its components and economic returns. Nitrogen was applied in two, three and four splits, besides a basal dose at the rates of 120,160 and $200 \mathrm{Kg} / \mathrm{ha}$. The MTR did not respond to increasing $\mathrm{N}$ level from 120 to $200 \mathrm{~kg} / \mathrm{ha}$, though the yield levels improved substantially (11.35\%) Application of nitrogen in four splits (Initial tillering (IT), tillering (T), Active tillering AT) and Panicle initiation (PI) and three splits (IT, AT and PI) significantly enhanced the grain and straw yields with better net returns over two splits (AT and PI) indicating the importance of a different fertilizer schedule for MTR over transplanted rice.

\section{Introduction}

Rice (Oryza sativa L.) is one of the most important cereal crop and staple food of India. At the current growth rate of population $(1.55 \%)$ in India, the requirement of rice by 2020 would be around 120-135 million tonnes (Raj et al., 2016). Direct seeding of rice and transplanting are the two common methods of rice establishment (Kumar et al., 2017). Transplanting method is more popular among farmers due to higher yield and less weed growth as compared to direct seeded rice. However, it requires high energy and also it is labour intensive (Guru et al., 2018). Machine transplanting of rice (MTR) has been considered the most promising option, as it saves labour, ensures timely transplanting and attains optimum plant density that contributes to high productivity (Negalur and Halepyati, 2017). The positive response to nitrogen application in rice has been reported but its time of application contributes significantly towards nitrogen use efficiency and rice 
productivity. Nitrogen moves very rapidly in the soil and subjected to various losses mainly due to leaching, denitrfication, volatilization and surface runoff resulting into reduced nitrogen use efficiency. To overcome this problem, split application of nitrogen is recommend and response per unit of nitrogen in rice was reported to be more when applied in split doses (Singh et al., 2017).

The crop management practices of MTR are entirely different from those adopted in manual transplanted rice in many ways viz. transplanting young seedlings, maintaining very shallow water depth during early stages of crop growth, giving wider row spacing and inter cultivation with power operated weeders. Early duration rice varieties (120-125 days) normally attain the panicle initiation stage in 45-47 days after transplanting in case of manual transplanting whereas in MTR the crop attains this stage in 55-58 days extending the period of tillering in MTR significantly (Negalur and Halepyati, 2017).

Taking into consideration these, it was hypothesized that $\mathrm{N}$ requirement of MTR at different growth stages can be met by increasing the number of splits with varying doses of $\mathrm{N}$ and consequently a study was conducted in this area of research.

\section{Materials and Methods}

A field experiment was conducted during Kharif season of 2012 at Rice Section, ARI, Rajendranagar, Hyderabad, Telangana $\left(17^{\circ} 19^{\prime} \mathrm{N}, 78^{\circ} 23^{\prime} \mathrm{E}, 542 \mathrm{~m}\right.$ above mean sea level). The soil of the experimental field was clay loam with $\mathrm{pH} 7.9$, organic carban $0.32 \%$ and the available $\mathrm{N}, \mathrm{P}_{2} \mathrm{O}_{5}$ and $\mathrm{K}_{2} \mathrm{O}$ were 163 , 74 and $869 \mathrm{~kg} / \mathrm{ha}$ respectively. The total rainfall received in 27 rainy days from transplanting $(22 / 7 / 2012)$ to physiological maturity (2/11/2012) was $293.4 \mathrm{~mm}$. The mean maximum and mean minimum temperatures recorded were $30.3^{\circ} \mathrm{c}$ and $18.5^{\circ} \mathrm{c}$ respectively and the season was quite normal. The experiment was replicated thrice with nine treatmental combinations in split plot design comprising 3 nitrogen rates as main plots (120, 160 and $200 \mathrm{~kg} \mathrm{~N} / \mathrm{ha}$ ) and 3 nitrogen schedules as sub plots viz. $\mathrm{N}$ as three equal splits at basal (B), active tillering (AT) and panicle initiation (PI). The most popular variety, MTU 1010 of 125 days duration was used in the experimentation.

The selected field was ploughed twice with tractor drawn cultivator in summer, later 15 days before transplanting the field was puddled with tractor drawn rotavator with 5-7 $\mathrm{cm}$ standing water and again two days before machine transplanting. The soil was allowed to settle for 48 hours before the transplanting machine entered the field. Seed of MTU 1010 rice variety were soaked for 24 hours and then incubated for another 12 hours. The nursery tray $(58 \times 28 \mathrm{~cm})$ was filled with the mixture of 3:1 soil: FYM free from clods and pebbles and then the sprouted seed was seeded with seeding machine @ 160g seed / tray and watering was done. The trays were shifted to the nursery field and covered with straw for shading. For first three days watering was done gently with rose cans without distributing the seed masses, later the watering was given through irrigation channels. After six days, the straw was removed and nursery was exposed to sunlight. The nursery was regularly irrigated, maintained well and transplanting was done with 17 days age seedlings on 22//2012 with walking type 4 line kuboto transplanter. The row to row spacing was $30 \mathrm{~cm}$ and within row it was $14-16 \mathrm{~cm}$ with 3-4 seedlings / hill. For one hectare, 175 trays were used. Entire experimental field was planted at once and then it was divided into plots of $7.2 \times 5.0 \mathrm{~m}$ by forming $20 \mathrm{~cm}$ temporary bunds within the replications. In between each replication, $60 \mathrm{~cm}$ width irrigation channels were prepared for irrigation/drainage. 
Sufficient care was taken to prevent the movement of applied nitrogen from one plot to the another. Entire phosphorus (60 kg/ha), half the dose of potassium $(20 \mathrm{~kg} / \mathrm{ha})$ and nitrogen as per the designated treatments were applied basally and thereafter. At panicle initiation the remaining potassium $(20 \mathrm{~kg} / \mathrm{ha})$ was applied along with nitrogen. The IT, T, AT and PI stages appeared at 15, 35, 45 and 58 DAT, respectively and the fertilizers were scheduled accordingly. Data on grain yield and its components were recorded and statistically analysed. The cost economics was worked out as per the prevailing market prices.

\section{Results and Discussion}

In machine transplanted rice, the yield attributes were not significantly influenced by the nitrogen levels and their scheduling. Interaction effect between nitrogen rate and timing was not found significant with respect to plant height, yield attributes and yield. Maximum plant height $(100.0 \mathrm{~cm})$ was recorded with $160 \mathrm{~kg} \mathrm{~N} / \mathrm{ha}$ followed by $200 \mathrm{~kg}$ $\mathrm{N} / \mathrm{ha}(98.8 \mathrm{~cm})$ and $120 \mathrm{~kg} \mathrm{~N} / \mathrm{ha}(95.8 \mathrm{~cm})$. Of the different $\mathrm{N}$ schedules, more split applications $\left(\mathrm{S}_{3}\right)$ recorded better plant height $(99.0 \mathrm{~cm})$. The tillers as well as panicle number increased with increase in nitrogen level from 120 to $200 \mathrm{~kg} /$ ha by 8.2 and $10.9 \%$, respectively. Nitrogen split application from three to four / five numerically improved the yield attributes viz., tillers and panicles. The maximum number of panicles $\left(417 / \mathrm{m}^{2}\right)$ was recorded when nitrogen was applied at B. IT, AT, $\mathrm{T}$ and PI indicating that higher split applications ensured $\mathrm{N}$ supply at critical growth stages of the crop.

Increasing the $\mathrm{N}$ rates had no significant influence on grain and straw yield of MTR, where as more number of split applications exhibited considerable impact on grain yield. Enhancement of $\mathrm{N}$ from 120 to $200 \mathrm{~kg} / \mathrm{ha}$ increased the grain yields from 6398 to 7262 $\mathrm{kg} / \mathrm{ha}(13.5 \%$ improvement) but not reached the level of significance. Fageria and Baligar (2001) reported that rice grain yield increased with increase $\mathrm{N}$ supply but up to certain limit only as was observed in the present study. Highest grain yield (7209 kg/ha) was obtained when $\mathrm{N}$ was applied in 5 equal splits $\left(\mathrm{S}_{3}\right)$ and it was at par with $\mathrm{N}$ application in 4 equal splits $\left(\mathrm{S}_{2}-781 \mathrm{~kg} / \mathrm{ha}\right)$, however it is interesting to note that these two schedules significantly recorded higher grain yield over 3 equal splits $\left(\mathrm{S}_{1}-6171 \mathrm{~kg} / \mathrm{ha}\right)$. This was primarily due to higher $\mathrm{N}$ use efficiency and reduction in $\mathrm{N}$ losses (denitrifications and leaching) on account of $\mathrm{N}$ application in four / three splits than in two splits (Mahajan et al., 2011). Similar trend was also observed in case of straw yield.

Economic analysis of the different nitrogen rates and schedules indicated that higher net return (Rs.57406/ha) as well as returns per rupee invested (1.55) were associated with higher nitrogen level $(200 \mathrm{~kg} / \mathrm{ha})$ and these values were low i.e., Rs.47174/ha and 1.31 respectively with $120 \mathrm{~kg} / \mathrm{ha}$. $\mathrm{N}$ in five splits at B, IT, T, AT and PI resulted in net returns of RS. 56717/ha with a return of 1.53 rupees per every rupee invested, whereas with three split applications. (B, AT and PI) the net income was only Rs.44262/ha (-12455/ha) and return per every rupee invested was only $1.23(-0.3)$.

For MTR, nitrogen scheduling as IT, AT, T and PI besides basal application recommended for higher grain and straw yields. The net returns as well as returns per rupee invested were also higher with this practice (Fig. 1 and Table 1). 
Table.1 Plant height, yield attributes, yield and economics as influenced by nitrogen rates and timing in machine transplanted rice

\begin{tabular}{|c|c|c|c|c|c|c|c|}
\hline Treatment & $\begin{array}{l}\text { Plant } \\
\text { height } \\
(\mathrm{cm})\end{array}$ & $\begin{array}{l}\text { Tillers } \\
\text { / sq.m }\end{array}$ & $\begin{array}{l}\text { Panicles } \\
\text { / sq.m }\end{array}$ & $\begin{array}{l}\text { Grain } \\
\text { yield } \\
\text { (kg/ha) }\end{array}$ & $\begin{array}{l}\text { Straw } \\
\text { yield } \\
\text { (kg/ha) }\end{array}$ & $\begin{array}{l}\text { Net } \\
\text { returns } \\
\text { (Rs./ha) }\end{array}$ & $\begin{array}{c}\text { Net } \\
\text { returns } \\
\text { (Rs./Re.) }\end{array}$ \\
\hline \multicolumn{8}{|c|}{ Nitrogen rate } \\
\hline $\mathrm{N}_{1}-120 \mathrm{~kg} / \mathrm{ha}$ & 95.8 & 415 & 380 & 6398 & 7038 & 47174 & 1.31 \\
\hline $\mathrm{N}_{2}-160 \mathrm{~kg} / \mathrm{ha}$ & 100.0 & 437 & 405 & 6805 & 7494 & 51965 & 1.42 \\
\hline $\mathrm{N}_{3}-200 \mathrm{~kg} / \mathrm{ha}$ & 98.8 & 449 & 416 & 7262 & 8015 & 57406 & 1.55 \\
\hline SEd+ & 1.21 & 15.8 & 13.7 & 384 & 421 & - & - \\
\hline C.D. $(p=0.05)$ & NS & NS & NS & NS & NS & - & - \\
\hline \multicolumn{8}{|c|}{ Nitrogen timing } \\
\hline $\begin{array}{c}\mathrm{S}_{1^{-}}{ }^{\prime} N^{\prime} 3 \text { equal splits at basal }(\mathrm{B}) \\
\text { active tillering } \mathrm{AT}) \text { and Panicle } \\
\text { initiation (PI) }\end{array}$ & 97.6 & 414 & 380 & 6174 & 6809 & 44262 & 1.23 \\
\hline $\begin{array}{c}\mathrm{S}_{2}-{ }^{\prime} \mathrm{N} \text { ' } 4 \text { equal splits at B, initial } \\
\text { tillering (IT), AT and PI }\end{array}$ & 98.0 & 437 & 405 & 7081 & 7718 & 55553 & 1.52 \\
\hline $\begin{array}{c}\mathrm{S}_{2}-{ }^{6} \mathrm{~N} ' 5 \text { equal splits at B, IT, AT, } \\
\text { Tillering and PI }\end{array}$ & 99.0 & 450 & 417 & 7209 & 8021 & 56717 & 1.53 \\
\hline SE d+ & 1.14 & 19.3 & 18.2 & 258 & 298 & - & - \\
\hline C.D. $(p=0.05)$ & NS & NS & NS & NS & NS & - & - \\
\hline
\end{tabular}

Fig.1 Yield of Machine transplanted rice as influenced by Nitrogen rates and timing

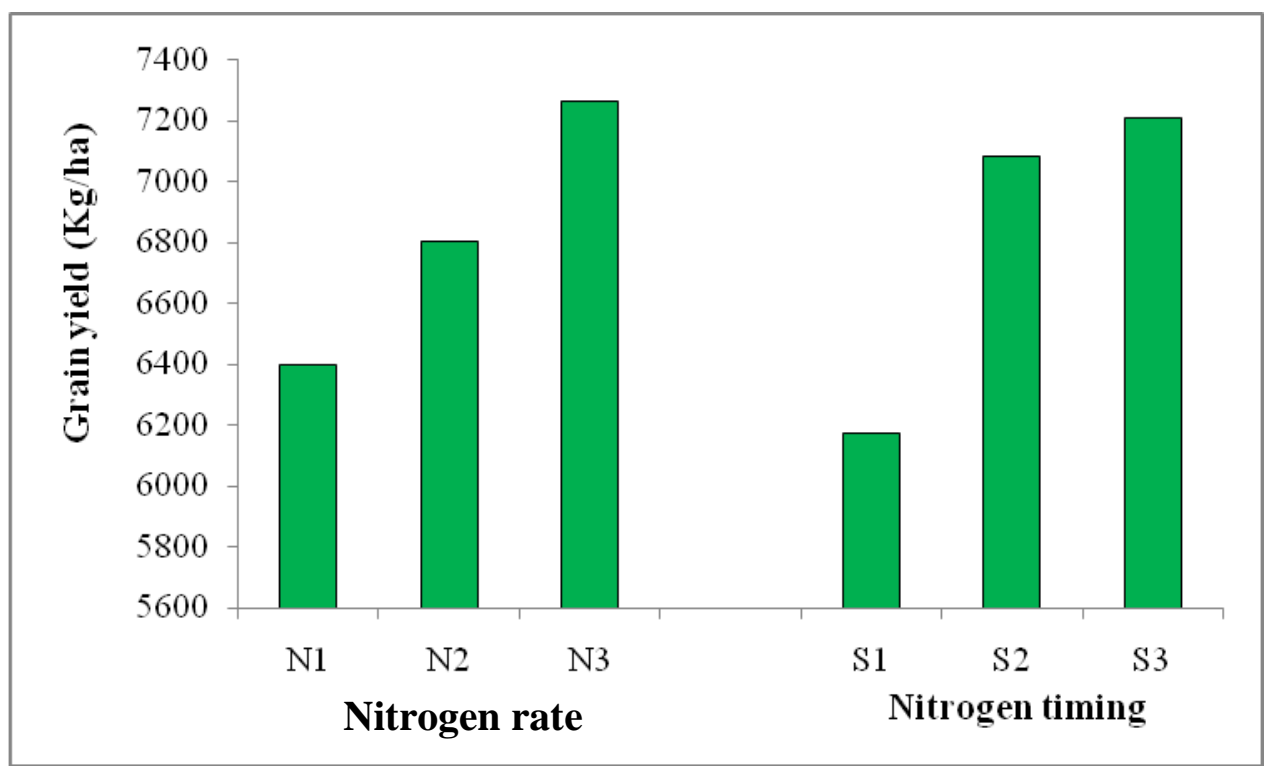




\section{References}

Fageria, N. K., and Baligar, V. C. (2001). Lowland rice response to nitrogen fertilization. Communications in Soil Science and Plant Analysis, 32(9-10), 1405-1429.

Guru, P. K., Chhuneja, N. K., Dixit, A., Tiwari, P., and Kumar, A. (2018). Mechanical transplanting of rice in India: status, technological gaps and future thrust. Oryza, 55(1), 100-106.

Kumar, A., Nayak, A. K., Pani, D. R., and Das, B. S. (2017). Physiological and morphological responses of four different rice cultivars to soil water potential based deficit irrigation management strategies. Field Crops Research, 205, 78-94.

Mahajan, G., Chauhan, B. S., and Gill, M. S. (2011). Optimal nitrogen fertilization timing and rate in dry-seeded rice in northwest India. Agronomy Journal,
103(6), 1676-1682.

Negalur, R.B. and Halepyati, A.S. 2017. Growth and Yield of Machine Transplanted Rice (Oryza sativa L.) as Influenced by Age and Number of Seedlings. International Journal of Current Microbiology and Applied Sciences 6(6): 376-385.

Raj R, Kumar A, Kumar V, Singh CB and Pandey UC. 2016. Herbicide options for controlling weeds in transplanted rice (Oryza sativa) under North Eastern Plains Zone. Indian Journal of Agronomy 61(2): 197-203.

Singh, S. K., Abraham, T., Kumar, R., and Kumar, R. (2017). Response of crop establishment methods and split application of nitrogen on productivity of rice under irrigated ecosystem. Environment and Ecology, 35(2A), 859-862.

\section{How to cite this article:}

Raghu Rami Reddy, P. 2019. Optimization of Nitrogen Fertilization Timing and Rate in Machine Transplanted Rice. Int.J.Curr.Microbiol.App.Sci. 8(11): 1017-1021.

doi: https://doi.org/10.20546/ijcmas.2019.811.119 